\title{
Haemolytic uraemic syndromes in the British Isles, 1985-8: association with Verocytotoxin producing Escherichia coli. Part 2: microbiological aspects
}

\author{
H Kleanthous, H R Smith, S M Scotland, R J Gross, B Rowe, C M Taylor, D V Milford
}

\begin{abstract}
In a three year study of children under 16 years with haemolytic uraemic syndrome faecal samples were examined for the presence of Verocytotoxin producing Escherichia coli (VTEC) using DNA probes and for free neutralisable Verocytotoxin in a Vero cell assay with specific antisera. There was evidence of VTEC infection in 58 of $185(31 \%)$ samples. A total of 53 VTEC was identified from patients with haemolytic uraemic syndrome. Thirty eight VTEC belonged to serotype $0157: H 7$ or $0157: H-, 34$ produced VT2 only, and four strains produced both VT1 and VT2. The remaining 15 VTEC belonged to nine different 0 serogroups; three strains produced VT1, 10 produced VT 2 , and two were positive for VT1 and VT2. Three control groups of patients without haemolytic uraemic syndrome were also examined. There was evidence of VTEC infection in $8 \%, 6 \%$, and $4 \%$ of specimens from individuals with bloody diarrhoea, those with diarrhoea only, and healthy controls respectively. VTEC from the bloody diarrhoeal and diarrhoeal controls were 0157:H7 but those from the healthy controls could not be 0 serogrouped. This study confirms the association of VTEC, and particularly strains of $0157: \mathrm{H7}$, with haemolytic uraemic syndrome. Strains producing VT1, VT2, or both toxins were isolated, although over $94 \%$ of VTEC produced VT2 alone or together with VT1.
\end{abstract}

Haemolytic uraemic syndrome is a major cause of acute renal failure in childhood. ${ }^{12}$ Infection with Shigella dysenteriae type 1 can lead to haemolytic uraemic syndrome, ${ }^{3}{ }^{4}$ but other micro-organisms have been suggested as a cause of haemolytic uraemic syndrome. In 1983 Karmali and colleagues working in Canada reported the isolation of Verocytotoxin producing Escherichia coli (VTEC) from cases of haemolytic uraemic syndrome. ${ }^{5}$ Verocytotoxin was first described by Konowalchuk et al, who showed that certain strains of $E$ coli produced a cytotoxin active on Vero cells. ${ }^{6}$ Two types of Verocytotoxin have been described, VT1 and VT2. ${ }^{7}$ VT1 is neutralised by an antiserum to Shiga toxin, produced by strains of $S$ dysenteriae type $1,{ }^{8}$ whereas VT2 is not neutralised by antiShiga toxin or anti-VT1. ${ }^{7}$ Another disease associated with VTEC, particularly strains of serotype $0157: \mathrm{H} 7$, is haemorrhagic colitis, ${ }^{9}$ and in most cases of haemolytic uraemic syndrome there is a bloody diarrhoeal prodrome. Haemorrhagic colitis and haemolytic uraemic syn- drome form an important part of a wide range of illness associated with VTEC. ${ }^{10}$

Forty children with haemolytic uraemic syndrome were investigated by Karmali et al and evidence of VTEC infection was obtained in $75 \%$ of cases. ${ }^{511}$ Evidence came from the following tests: isolation of VTEC, demonstration of specifically neutralisable faecal Verocytotoxin, and a significant rise in Verocytotoxin neutralising antibody titre in acute and convalescent sera. The VTEC strains belonged to serogroups $026,0111,0113,0121,0145$, and 0157. ${ }^{5}$ In 1983 an outbreak of haemolytic uraemic syndrome occurred in the West Midlands and VTEC of serotype 0157:H7 were isolated from the faeces of some patients. ${ }^{12}$ In a subsequent study to investigate the association between VTEC infection and haemolytic uraemic syndrome in children in the United Kingdom, Scotland et al reported that there was evidence of VTEC infection in 22 of 66 cases of haemolytic uraemic syndrome. ${ }^{13}$ Verocytotoxin producing strains of serogroup 0157 were involved in 15 of 19 cases where VTEC were isolated. The other strains belonged to serotypes 026:H11, 0104:H2, 0153:H25, and 0163:H19. Cases of haemolytic uraemic syndrome associated with VTEC infection have been reported in several other countries including the United States, ${ }^{14}{ }^{15}$ Germany, ${ }^{16}$ Australia, ${ }^{17}$ and Argentina. ${ }^{18}$

The clinical and epidemiological features of a collaborative study involving the Division of Enteric Pathogens at the Central Public Health Laboratory, the British Paediatric Surveillance Unit, and the British Association of Paediatric Nephrologists are presented in the accompanying paper. ${ }^{19}$ This paper describes the results of examining faecal specimens and cultures, from patients with haemolytic uraemic syndrome and control groups, for evidence of VTEC infection.

\section{Patients and methods}

STUDY POPULATION

From 1 April 1985 to 31 March 1988, children under the age of 16 years with haemolytic uraemic syndrome or in one of the control groups were admitted to the study. The three control groups were children with acute bloody diarrhoea without evidence of haemolytic uraemic syndrome, children with diarrhoea but not haemolytic uraemic syndrome, and a group of healthy controls.

EXAMINATION OF FAECAL SPECIMENS

The faecal samples from cases were examined in

Correspondence to: Dr Smith. 
the local laboratory for the presence of salmonella, shigella, campylobacter, enteropathogenic $E$ coli (EPEC), and other pathogens; the results of these investigations are given in the accompanying paper. ${ }^{19}$ Similar tests were performed with specimens from the controls and the findings are presented in the results section. Upon receipt in this laboratory faecal samples were resuspended in an equal volume of phosphate buffered saline or diluted further if necessary. The specimens were then subjected to the following tests:

(1) Presence of free Verocytotoxin in faeces ${ }^{5} 13$ The faecal suspensions were centrifuged and the supernatants filtered (Acrodisc 0.45 microns, Gelman Sciences). Dilutions in tissue culture medium of a faecal filtrate were tested for cytotoxic activity on Vero cells and Y1 mouse adrenal tumour cells growing as monolayers in 96 well tissue culture microtitre plates. The titre of the cytotoxic activity was expressed as the highest dilution which had a detectable cytotoxic effect on a monolayer of cells after incubation for four days at $37^{\circ} \mathrm{C}$. Filtrates that had a cytotoxic effect on Vero cells but not Y1 cells were examined further in neutralisation experiments. Details of the neutralisation tests and the preparation of antisera have been reported previously. ${ }^{13}$

\section{(2) Preparation of membranes for DNA hybridisation tests}

The faecal suspensions were diluted to one in $10^{6}$ in phosphate buffered saline and $0.1 \mathrm{ml}$ samples of each dilution were spread on MacConkey agar and incubated overnight at $37^{\circ} \mathrm{C}$. For each specimen a plate with several hundred well separated colonies was replicated on to nylon (Hybond-N, Amersham) membranes placed on MacConkey agar. The master plates and the replicas were incubated at $37^{\circ} \mathrm{C}$ for approximately six hours. The membranes were prepared for hybridisation as described previously. ${ }^{13}$

\section{(3) Presence of $E$ coli 0157 using sorbitol- MacConkey agar}

Each faecal suspension was used to inoculate sorbitol-MacConkey agar (Oxoid MacConkey agar No 3 containing $1 \%$ sorbitol). The plates were incubated overnight at $37^{\circ} \mathrm{C}$ and examined for colourless non-sorbitol fermenting colonies. If possible, five non-sorbitol fermenting colonies were streaked on MacConkey agar (Oxoid CM7) and after overnight incubation at $37^{\circ} \mathrm{C}$ were tested by slide agglutination with an 0157 antiserum. Any agglutinating colonies were identified as $E$ coli biochemically and their 0 serogroup was confirmed by tube agglutination using a heated suspension. ${ }^{20}$

TESTING BACTERIAL CULTURES FOR VEROCYTOTOXIN AND OTHER ENTEROTOXINS

Bacterial cultures were grown in $10 \mathrm{ml}$ trypticase soy broth at $37^{\circ} \mathrm{C}$ for 18 hours and sterile culture supernates were tested for Verocytotoxin as described previously. ${ }^{21}$ Neutralisation tests were performed by the method of Scotland et al. ${ }^{13}$ All strains positive for Verocytotoxin were tested for the production of heat stable and heat labile enterotoxins. ${ }^{13}$

PREPARATION OF DNA PROBES AND

HYBRIDISATION EXPERIMENTS

The VT1 probe was a $0.75 \mathrm{~kb}$ HincII fragment cloned from a Verocytotoxin encoding phage carried by $E$ coli strain H19, serotype 026:H11. ${ }^{22}$ The VT2 probe was a $0.85 \mathrm{~kb}$ AvaI$P s t I$ fragment obtained by cloning from a Verocytotoxin encoding phage carried by $E$ coli strain E32511, serotype 0157:H-. ${ }^{23}$ The probe fragments were cut from low gelling temperature agarose and labelled by the random primer method using deoxyadenosine $5^{\prime}-\alpha\left({ }^{35} S\right)$ thiotriphosphate (Amersham). DNA hybridisation was at $42^{\circ} \mathrm{C}$ in a mixture containing $50 \%$ formamide. ${ }^{24}$ Washing under high stringency conditions and autoradiography were as described previously. ${ }^{22}$ Autoradiographs were examined with the master plates for colonies that hybridised with either probe or both probes. These strains were identified biochemically, serotyped and examined for Verocytotoxin production.

\section{CHARACTERISATION OF VTEC STRAINS OF} SEROGROUP OI 57

The VTEC strains belonging to serogroup 0157 isolated in this study were tested for colicin production, resistance to antimicrobial agents, and for their plasmid DNA content. ${ }^{25}$ The 0157 strains were also phage typed using the scheme developed in Canada and extended in this laboratory. ${ }^{26} 27$

\section{Results}

TESTING OF SAMPLES FROM CASES OF HAEMOLYTIC URAEMIC SYNDROME

Faecal specimens from 196 cases of haemolytic uraemic syndrome were examined. Coliforms were isolated from 185 of the faecal specimens and several hundred individual colonies from each sample were tested for hybridisation with DNA probes for VT1 and VT2. Fifty two of the 185 samples were probe positive (table 1) and the percentage of probe positive colonies ranged from $<1 \%$ to $95 \%$.

Free faecal Verocytotoxin, neutralisable by specific antisera to VT1, VT2, or both toxins, was detected in 38 of 184 specimens tested. Not all the samples were tested as insufficient material was available in some instances. The toxin titres covered a wide range, from 20 to 10000 . There was free Verocytotoxin in 31 of the 52 samples in which VTEC had been isolated from the faecal specimens. Verocytotoxin that was neutralisable was demonstrated in five specimens giving no VTEC and in one specimen from which no coliforms were grown (table 2). From one additional sample specific faecal Verocytotoxin was detected but there was insufficient material for neutralisation tests. Therefore, combining the results of both methods, there was evidence of VTEC infection in 58 of the $185(31 \%)$ cases of haemolytic uraemic syndrome in which faeces had yielded 
Table 1 Evidence of VTEC infection in cases of haemolytic uraemic syndrome and control groups

\begin{tabular}{|c|c|c|c|c|}
\hline & $\begin{array}{l}\text { Haemolytic } \\
\text { uraemic syndrome }\end{array}$ & $\begin{array}{l}\text { Bloody diarrhoea, } \\
\text { no haemolytic } \\
\text { uraemic syndrome }\end{array}$ & $\begin{array}{l}\text { Diarrhoea, } \\
\text { no haemolytic } \\
\text { uraemic syndrome }\end{array}$ & $\begin{array}{l}\text { Healthy } \\
\text { controls }\end{array}$ \\
\hline $\begin{array}{l}\text { Total No tested } \\
\text { No of samples with coliform growth } \\
\text { No with VTEC } \\
\text { No with VTEC and neutralisable faecal }\end{array}$ & $\begin{array}{c}196 \\
185 \\
52^{*}\end{array}$ & $\begin{array}{r}50 \\
48 \\
3\end{array}$ & $\begin{array}{r}62 \\
54 \\
1\end{array}$ & $\begin{array}{r}51 \\
46 \\
2\end{array}$ \\
\hline $\begin{array}{l}\text { Verocytotoxin } \\
\text { No with VTEC, neutralisable faecal Vero- }\end{array}$ & 31 & 0 & 0 & 0 \\
\hline $\begin{array}{l}\text { cytotoxin not detected } \\
\text { No with neutralisable faecal Verocytotoxin in the }\end{array}$ & $21 \dagger$ & 3 & 1 & 2 \\
\hline $\begin{array}{l}\text { absence of VTEC } \\
\text { No with coliform growth and evidence of VTEC }\end{array}$ & $6 \ddagger$ & 1 & 2 & 0 \\
\hline infection & 58 & 4 & 3 & 2 \\
\hline
\end{tabular}

*One specimen had VTEC belonging to two different serotypes.

This includes one sample for which a faecal Verocytotoxin test could not be performed.

¥This includes one sample in which specific faecal Verocytotoxin was detected but there was insufficient material for neutralisation tests.

In one additional sample neutralisable Verocytotoxin was demonstrated but no growth was obtained.

Table 2 Faecal samples with neutralisable Verocytotoxin in the absence of VTEC

\begin{tabular}{lrll}
\hline Study group & Toxin titre* & \multicolumn{2}{l}{ Neutralisation } \\
\cline { 3 - 4 } & & anti-VTI & anti-VT2 \\
\hline Haemolytic uraemic & 100 & NT & NT \\
syndrome & 2000 & No & Yes \\
& 40 & No & Yes \\
& 5000 & No & Yes \\
& 20 & No & Yes \\
& 450 & No & Yes \\
$\begin{array}{l}\text { Bloody diarrhoea, no } \\
\text { haemolytic uraemic }\end{array}$ & 2500 & Yes & No \\
syndrome & & & \\
$\begin{array}{c}\text { Diarrhoea, no haemolytic } \\
\text { uraemic syndrome }\end{array}$ & 43700 & Yes & No \\
\hline
\end{tabular}

NT $=$ Not tested, because insufficient material was available.

${ }^{*}$ Toxin activity detected on Vero cells but not $\mathbf{Y}_{1}$ cells.

coliform growth. Comparison of the results of neutralisation tests with the DNA probe experiments showed there was agreement regarding the type of Verocytotoxin present in 28 of 31 samples in which both VTEC and faecal Verocytotoxin were demonstrated. In two cases hybridisation with both probes was detected but there was only neutralisation with anti-VT2. In the remaining sample colonies hybridised with VT2 but the faecal Verocytotoxin was only neutralised by using both antisera.

TESTING OF SAMPLES FROM CONTROL GROUPS Faecal samples from the control groups were examined for pathogens other than VTEC in the local laboratories. From the $\mathbf{5 0}$ cases with bloody diarrhoea but not haemolytic uraemic syndrome the following organisms were isolated: Shigella flexneri $(\mathrm{n}=1)$, campylobacter $(\mathrm{n}=1), \operatorname{EPEC}(\mathrm{n}=1), \mathrm{EPEC}$ and Giardia lamblia $(n=1)$, EPEC and aeromonas $(n=1)$, and campylobacter plus rotavirus $(n=1)$. In the 62 cases with non-bloody diarrhoea but not haemolytic uraemic syndrome the results were as follows: Salmonella typhimurium $(\mathrm{n}=1), \operatorname{EPEC}(\mathrm{n}=3)$, aeromonas $(n=2), G$ lamblia $(n=1)$, cryptosporidium $(n=1)$, rotavirus $(n=10)$, and cryptosporidium plus $G$ lamblia $(n=1)$. No pathogens were reported for the healthy control group.

Tests in this laboratory showed that of the $\mathbf{5 0}$ faecal samples from children with bloody diarrhoea but not haemolytic uraemic syndrome (table 1) 48 grew coliforms and there was evidence of VTEC infection in four cases. VTEC were isolated from three samples and free neutralisable Verocytotoxin, using an antiserum to VT1, was detected in one specimen that was probe negative (table 2). Sixty two samples of faeces from children with non-bloody diarrhoea, but not haemolytic uraemic syndrome, were tested and 54 grew coliforms (table 2). VTEC were isolated from one sample and neutralisable faecal Verocytotoxin, using an antiserum to VT1, was found in two other samples that were probe negative. One of the samples with faecal Verocytotoxin also contained rotavirus. In the healthy control group, 46 of 51 specimens had coliform growth and VTEC were isolated from two samples (table 1).

\section{SEROTYPES AND TOXIN TYPES OF THE VTEC STRAINS}

The serotypes and toxin types of the VTEC isolated from the cases with haemolytic uraemic syndrome and controls during the study are summarised in table 3 . A total of 53 VTEC was identified from patients with haemolytic uraemic syndrome with one specimen containing VTEC belonging to two different serotypes 0115:H10 and 0157:H7. All 53 probe positive strains produced Verocytotoxin active in tissue culture tests; none of the VTEC produced heat stable or heat labile enterotoxins. Thirty eight of the VTEC belonged to serotype $0157: \mathrm{H} 7$ or 0157:H-; 34 of these strains produced VT2 only and four strains produced both VT1 and VT2. The remaining VTEC belonged to nine different 0 serogroups and one strain had an unidentifiable 0 antigen. VTEC were isolated from six samples in the control groups (table 3). Three strains of 0157 were detected in specimens from patients with bloody diarrhoea and one 0157 strain from a case in the non-bloody diarrhoea control group. In the healthy controls the two VTEC strains could not be 0 serogrouped because they were autoagglutinable, one was of flagellar type $\mathrm{H} 2$ and the other was H10.

USE OF SORBITOL MACCONKEY AGAR AND AN OI57 ANTISERUM FOR THE DETECTION OF STRAINS BELONGING TO SEROGROUP OI 57 VTEC of serotype 0157:H7 or H- do not ferment sorbitol rapidly, ${ }^{28}$ and MacConkey agar 
Table 3 Serotypes and toxin types of VTEC strains

\begin{tabular}{|c|c|c|c|c|c|c|}
\hline \multirow[t]{2}{*}{ Study group } & \multirow[t]{2}{*}{$\begin{array}{l}\text { Serotype of } \\
\text { VTEC }\end{array}$} & \multirow{2}{*}{\multicolumn{2}{|c|}{$\begin{array}{l}\text { Verocytotoxin } \\
\text { type }\end{array}$}} & \multirow[t]{2}{*}{$\begin{array}{l}\text { No of } \\
\text { strains }\end{array}$} & \multirow{2}{*}{$\begin{array}{l}\text { Prodrome } \\
\text { Bloody } \\
\text { diarrhoea }\end{array}$} & \multirow[b]{2}{*}{ Diarrhoea } \\
\hline & & & & & & \\
\hline \multirow[t]{2}{*}{ Haemolytic uraemic syndrome } & $\begin{array}{l}\text { 0157:H7 } \\
0157: \mathrm{H7} \\
0157: \mathrm{H}- \\
\text { 05:H- } \\
\text { 026:H11 } \\
\text { 026:H11 } \\
\text { 055:H7 } \\
\text { 055:H10 } \\
\text { 0105ac:H18 } \\
\text { 0115:H10 } \\
\text { 0128ab:H25 } \\
\text { 0145:H25 } \\
\text { 0163:H19 } \\
\text { 0165:H25 } \\
\text { 0?:H- }\end{array}$ & $\begin{array}{l}\text { VT1 } \\
\text { VT1 } \\
\text { VT1 }\end{array}$ & $\begin{array}{l}\text { VT2 } \\
\text { VT2 } \\
\text { VT2 } \\
\text { VT2 } \\
\text { VT2 } \\
\text { VT2 } \\
\text { VT2 } \\
\text { VT2 } \\
\text { VT2 } \\
\text { VT2 } \\
\text { VT2 } \\
\text { VT2 } \\
\text { VT2 }\end{array}$ & $\begin{array}{c}4 \\
31^{*} \\
3 \\
1 \\
2 \\
1 \\
1 \\
1 \\
1 \\
1^{*} \\
1 \\
2 \\
1 \\
2 \\
1\end{array}$ & $\begin{array}{l}1 \\
1 \\
1 \\
1 \\
1 \\
1\end{array}$ & $\begin{array}{l}2 \\
4 \\
1 \\
1 \\
1 \\
1\end{array}$ \\
\hline & & Total & & 53 & 40 & 13 \\
\hline $\begin{array}{l}\text { Bloody diarrhoea, no haemolytic uraemic } \\
\text { syndrome }\end{array}$ & $\begin{array}{l}\text { 0157:H7 } \\
\text { 0157:H7 }\end{array}$ & VT1 & $\begin{array}{l}\text { VT2 } \\
\text { VT2 }\end{array}$ & $\begin{array}{l}1 \\
2\end{array}$ & & \\
\hline Diarrhoea, no haemolytic uraemic syndrome & 0157:H7 & & VT2 & 1 & & \\
\hline Healthy controls & $\begin{array}{l}0 \text { rought:H2 } \\
0 \text { rought:H10 }\end{array}$ & $\begin{array}{l}\text { VT1 } \\
\text { VT1 }\end{array}$ & $\begin{array}{l}\text { VT2 } \\
\text { VT2 }\end{array}$ & $\begin{array}{l}1 \\
1\end{array}$ & & \\
\hline
\end{tabular}

${ }^{*}$ VTEC of serotypes 0115: $\mathrm{H10}$ and 0157:H7 were isolated from one specimen.

tThe 'rough' strains were autoagglutinable.

containing sorbitol has been used for the detection of possible 0157 strains. During part of the present study 112 specimens from cases of haemolytic uraemic syndrome were tested on sorbitol MacConkey agar. Testing of up to five colonies from each specimen with an 0157 antiserum detected $E$ coli 0157 in 22 of these samples. Non-sorbitol fermenting colonies were detected in another 36 of the 112 samples but none of the five colonies tested from these 36 specimens was 0157 . The DNA probe tests showed all the 22 samples, detected with the 0157 antiserum, were positive and in addition the probes detected VTEC of serogroup 0157 in eight more cases. In seven of the eight cases there were $12 \%$ or fewer colonies positive for Verocytotoxin in the hybridisation tests.

ISOLATION OF VTEC IN RELATION TO THE TYPE OF PRODROME

The 196 cases of haemolytic uraemic syndrome were analysed in relation to the type of prodromal illness and any evidence of VTEC infection. One hundred and forty three cases (73\%) had bloody diarrhoea, $42(21 \%)$ had diarrhoea without blood, and seven patients had no diarrhoea. In four cases there was no information regarding the prodrome.

Of the 143 cases with a bloody diarrhoeal prodrome 40 VTEC strains were isolated from the faeces of 39. Thirty two of the strains belonged to serogroup 0157 and eight strains were of seven other serogroups: from one sample VTEC of serogroups 0157 and 0115 were isolated (table 3 ). In the 42 patients with haemolytic uraemic syndrome with a nonbloody diarrhoeal prodrome VTEC were isolated from 13 samples and six belonged to serogroup 0157 and the other seven strains were of five other serogroups (table 3). VTEC were not isolated from the seven samples from patients without a diarrhoeal prodrome.

In seven cases there was detection of faecal Verocytotoxin but VTEC were not isolated (table 2). Four of these samples came from patients with a bloody diarrhoeal prodrome, two had diarrhoea, and in the other case information was not available.

TESTING OF SPECIMENS FROM FAMILY CONTACTS OF CASES OF HAEMOLYTIC URAEMIC SYNDROME Information as to whether family contacts had also suffered with haemolytic uraemic syndrome, diarrhoea, or bloody diarrhoea was available for $\mathbf{2 8 3}$ of the 288 patients with haemolytic uraemic syndrome included in the study, ${ }^{19}$ and there were reports of illness in the families of 65 patients. This information had been given for 49 of the 52 patients from whom VTEC had been isolated. Family members of 14 of 35 patients with 0157 VTEC suffered from diarrhoea or bloody diarrhoea and in six families a contact developed haemolytic uraemic syndrome. Family members of three of the 14 patients with VTEC belonging to other serogroups were ill but none developed haemolytic uraemic syndrome. Faecal specimens were available for testing from contacts of four patients infected with 0157 VTEC and strains of $E$ coli 0157 were isolated from three. Faecal specimens were also available from contacts of four patients with haemolytic uraemic syndrome for whom VTEC infection had not been confirmed; these contact specimens were all negative.

\section{TESTING OF MORE THAN ONE SAMPLE FROM} PATIENTS

For $\mathbf{4 0}$ of the patients with haemolytic uraemic syndrome more than one faecal specimen was tested and in 14 cases there was evidence of VTEC infection in at least one sample. There was considerable variation in the results obtained with multiple samples especially in relation to the proportion of VTEC among the coliforms and the titres of faecal Verocytotoxin. In seven of the 14 positive cases two samples were taken on the same day and in six of these 
Table 4 Properties of VTEC strains belonging to serogroup 0157

\begin{tabular}{|c|c|c|c|c|}
\hline Phage type & $\begin{array}{l}\text { Verocs } \\
\text { type }\end{array}$ & totoxin & $\begin{array}{l}\text { Plasmids } \\
(\text { molecular weight } \\
\left.\times 10^{6}\right)\end{array}$ & $\begin{array}{l}\text { No of strains } \\
(n=38)\end{array}$ \\
\hline $\begin{array}{r}1 \\
2 \\
4 \\
24 \\
49\end{array}$ & VT1 & $\begin{array}{l}\text { VT2 } \\
\text { VT2 } \\
\text { VT2 } \\
\text { VT2 } \\
\text { VT2 }\end{array}$ & $\begin{array}{l}55-63,4 \cdot 5-6 \cdot 3 \\
56-62 * \\
53 \dagger \\
55-58 \ddagger \\
53-58\end{array}$ & $\begin{array}{r}4 \\
25 \\
2 \\
2 \\
5\end{array}$ \\
\hline
\end{tabular}

*Eight strains also carried additional plasmids ranging in size from 1.9 to $48 \times 10^{6}$

tOne strain also carried a plasmid of $35 \times 10^{6}$

$\ddagger$ Both strains carried two plasmids of molecular weight 55 to $58 \times 10^{6}$.

both samples had evidence of VTEC infection. In the remaining case one sample was positive for VTEC and the other was negative for VTEC and faecal Verocytotoxin. For seven patients up to three samples were taken on different days. In one case the first sample was negative and a second sample, taken three days later, was positive. In other cases, where the information was available, with time there was generally a reduction in the frequency of isolation of VTEC and a drop in faecal Verocytotoxin titre.

FURTHER PROPERTIES OF 0157 VTEC STRAINS VTEC strains isolated from patients with haemolytic uraemic syndrome and belonging to serogroup 0157 were examined by phage typing and plasmid analysis in order to study the distribution of the different strains in Britain. The results are shown in table 4 .

Twenty five of the 38 strains belonged to phage type 2; all 25 strains carried a plasmid of 56 to $62 \times 10^{6}$ with eight of the strains possessing additional plasmids. The remaining 0157 VTEC strains belonged to four other phage types, 1, 4, 24 , and 49 . The phage type 1 strains produced VT1 and VT2 and colicin D and carried a small plasmid whereas strains of types 4,24 , and 49 produced VT2 alone and usually only had a single plasmid of 53 to $58 \times 10^{6}$. The two phage type 24 strains carried two plasmids of 55 to $58 \times 10^{6}$ and in both cases one plasmid encoded production of colicin I. Loss of the colicin I plasmid converted the phage type 24 strains to phage type $2 .{ }^{27}$ In general, strains of particular phage types were not restricted to a certain geographical area, although both strains of phage type 24 were isolated in Birmingham. All 380157 strains were sensitive to the 15 commonly used antibacterial agents ${ }^{25}$ tested in this study.

Four strains of serotype 0157:H7 were detected in the samples from the control groups (table 3). Three strains from the bloody diarrhoea controls belonged to phage types 2 (VT2), 4 (VT2), and 8 (VT1 and VT2). The 0157:H7 strain from the diarrhoea control group was of phage type 2 (VT2). Plasmid analysis showed the three VT2 strains carried a plasmid of $56 \times 10^{6}$ and the strain with VT1 and VT2 produced colicin $\mathrm{D}$ and possessed plasmids of $58 \times 10^{6}$ and $4.7 \times 10^{6}$.

\section{Discussion}

The microbiological findings of this three year study extend previous investigations on the association of VTEC and haemolytic uraemic syndrome in children. ${ }^{10}$ As reported in a previous study the use of tests for Verocytotoxin genes using DNA probes and for faecal Verocytotoxin with specific antisera showed evidence of VTEC infection in more cases than using either test alone. ${ }^{13}$ There is clearly a need for alternative tests, however, especially for the cases where the faecal samples were submitted several days after onset of the diarrhoeal prodrome. These could include testing serum samples that may be taken up to several weeks after the onset of infection. Patients with haemolytic uraemic syndrome and infected with 0157:H7 produce high titre serum antibodies to 0157 lipopolysaccharide. ${ }^{29}$ High titre antibodies to 0157 lipopolysaccharide were also detected in several sera from patients with haemolytic uraemic syndrome, not included in the present study, from whom VTEC were not isolated and faecal Verocytotoxin could not be demonstrated. ${ }^{30}$ The combination of examining sera as well as faeces should provide evidence of VTEC infection in a much higher proportion of patients with haemolytic uraemic syndrome.

During the study over $20 \%$ of the cases with haemolytic uraemic syndrome had family members suffering from diarrhoea or bloody diarrhoea. Because of insufficient information it was not possible to conclude whether the cases and family contacts had been infected from a single source or there had been person to person spread. Further studies are required to investigate this.

In this investigation the study of three control groups gave evidence of VTEC infection in $8 \%$, $6 \%$, and $4 \%$ from individuals with bloody diarrhoea, with diarrhoea, and healthy controls respectively. These figures contrast with the $31 \%$ of cases with haemolytic uraemic syndrome with evidence of VTEC infection. It is rather surprising that VTEC were isolated or faecal Verocytotoxin was demonstrated in only $8 \%$ of children with bloody diarrhoea as other studies in Britain have reported a much higher incidence of VTEC in cases of haemorrhagic colitis. ${ }^{31} 32$ These studies of haemorrhagic colitis have usually involved adults rather than children under 16 years as tested in the present study.

VTEC of serotype $0157: \mathrm{H} 7$ or $0157: \mathrm{H}-$ were predominant in the present study although VTEC belonging to 11 different serotypes other than $0157: \mathrm{H7}$ or $0157: \mathrm{H}$ - were isolated and this extends the range of serotypes associated with cases of haemolytic uraemic syndrome. VTEC belonging to serotypes $05: \mathrm{H}-, 055: \mathrm{H} 7,055: \mathrm{H} 10$, 0105ac:H18, 0115:H10, and 0165:H25 have not been reported previously in cases of haemolytic uraemic syndrome. VTEC other than 0157 were isolated from seven patients with a non-bloody diarrhoeal prodrome and from eight with a bloody diarrhoeal prodrome.

The use of sorbitol MacConkey agar and an 0157 antiserum is useful for the detection of VTEC belonging to serotype $0157: \mathrm{H} 7$ or $0157: \mathrm{H}-$ and identified $73 \%$ of the samples found to contain 0157 VTEC strains using the DNA probes. The use of sorbitol MacConkey 
agar, however, is not applicable for the detection of VTEC of other serogroups. As VTEC belonging to serogroups other than 0157 were isolated in a significant number of specimens improved tests are required for the detection of such strains in clinical laboratories.

Studies of the properties of the 0157 strains showed that strains which produced VT2 and belonged to phage type 2 were the predominant class. Such strains are widely distributed in Britain $^{27}$ and Canada ${ }^{33}$ and a strain of this type was responsible for an outbreak of haemorrhagic colitis in Birmingham in 1987, ${ }^{27} 34$ and also for a cluster of cases of haemolytic uraemic syndrome in the West Midlands in 1983.12 27

VTEC can cause serious human disease in Britain but little is known about the sources of the VTEC strains. In North American foods of animal origin appear to be a major source of 0157:H7 infecting humans and outbreaks of haemorrhagic colitis have been associated with the consumption of hamburgers and unpasteurised milk. ${ }^{10}$ Evidence for bovines being a reservoir for 0157:H7 also comes from the isolation of these bacteria from cattle in Canada, USA, Argentina, and Britain. ${ }^{1032}$ Examination of retail fresh meats and poultry for 0157:H7 in the USA and Canada showed that these organisms were present in 1.5 to $3.7 \%$ of samples of beef, pork, poultry, and lamb. ${ }^{35}$ Such information is not available in Britain and there is a need to establish whether VTEC infections in man are zoonotic in origin and to trace the vehicles of transmission.

This work was supported for two years by a grant from the National Kidney Research Fund. We thank colleagues who sent specimens from patients with haemolytic uraemic syndrome and the staff at East Birmingham Hospital, Birmingham Children's Hospital, and Queen Elizabeth Hospital for Children, London, who provided the samples for the control groups.

We also thank Mrs J Frost for performing the phage typing of the $\mathrm{E}$ coli 0157 strains.

1 Fong JSC, de Chadarevian JP, Kaplan BS. Hemolytic uremic syndrome. Current concepts and management. Pediatr $C l$ in syndrome. Current concepts an
North Am 1984;29:835-55.

2 Levin M, Walters MDS, Barratt TM. Hemolytic uremic syn drome. Advances in Pediatric Infectious Diseases 1989;4: drome.

3 Rahaman MM, Jamial Alam AKM, Islam MR, Greenough WB, Lindenbaum J. Shiga bacillus dysentery associated with marked leukocytosis and erythrocyte fragmentation. Fohns Hopkins Medical foumal 1975;136:65-70.

4 Koster F, Levin J, Walker C, et al. Hemolytic-uremic syndrome after shigellosis: relation to endotoxemia and circulating immune complexes. $N$ Engl $\mathcal{F}$ Med 1978;298: 927-33.

5 Karmali MA, Steele BT, Petric M, Lim C. Sporadic cases of haemolytic uraemic syndrome associated with faecal cytotoxin and cytotoxin-producing Escherichia coli in stools. Lancet 1983;

6 Konowalchuk J, Speirs JI, Stavric S. Vero response to a cytotoxin of Escherichia coli. Infect Immun 1977;18:775-9.

7 Scotland SM, Smith HR, Rowe B. Two distinct toxins active on Vero cells from Escherichia coli 0157. Lancet 1985;ii: 885-6.

8 O'Brien AD, LaVeck GD, Thompson MR, Formal SB. Production of Shigella dysenteriae type 1-like cytotoxin by Escherichia coli. 7 Infect Dis 1982;146:763-9.

9 Riley LW. The epidemiologic, clinical and microbiologic features of hemorrhagic colitis. Annu Rev Microbiol 1987,
10 Karmali $M$. Infection by Verocytotoxin-producing Escherichia coli. Clinical Microbiology Reviews 1989;2: 15-38.

11 Karmali MA, Petric M, Lim C, Fleming P, Arbus G, Lior H. The association between idiopathic hemolytic uremic syndrome and infection by Vero-toxin producing Escherichia coli. F Infect Dis 1985;151:775-82.

12 Taylor CM, White RHR, Winterborn MH, Rowe B. Haemolytic uraemic syndrome: clinical experience of an outbreak in the West Midlands. $\mathrm{Br}$ Med F 1986;292:1513-6.

13 Scotland SM, Rowe B, Smith HR, Willshaw GA, Gross RJ. Vero cytotoxin-producing strains of Escherichia coli from children with haemolytic uraemic syndrome and their detection by specific DNA probes. $\mathcal{F}$ Med Microbiol 1988; 25:237-43.

14 Spika JS, Parsons JE, Nordenberg D, Wells JG, Gunn RA, Blake PA. Hemolytic uremic syndrome and diarrhoea associated with Escherichia coli $0157: \mathrm{H} 7$ in a day care center. I Pediatr 1986;109:287-91.

15 Neill MA, Tarr PI, Clausen CR, Christie DL, Hickman RO. Escherichia coli 0157:H7 as the predominant pathogen associated with the hemolytic uremic syndrome: a prospective study in the Pacific Northwest. Pediatrics 1987;80: 37-40.

16 Bitzan $M$, Karch H, Altrogge H, Strehlau J, Bläker F. Hemolytic uremic syndrome associated with a variant Shiga-like cytotoxin of Escherichia coli 0111. Pediatr Infect Dis $\mathcal{f}$ 1988;7:128-32.

17 Gunzburg S, Gracey M, Forbes D, Hewitt I, Bettelheim K. Haemolytic uraemic syndrome and verocytotoxigenic Esch coli. Med f Aust 1988;149:54-5.

18 Lopez EL, Diaz M, Grinstein S, et al. Hemolytic uremic syndrome and diarrhea in Argentine children: the role of Shiga-like toxins. F Infect Dis 1989;160:469-75.

19 Milford DV, Taylor CM, Guttridge B, Hall S, Rowe B, Kleanthous H. Haemolytic uraemic syndromes in Britain 1985-8: association with Verocytotoxin producing Escher1985-8: association with Verocytotoxin producing Escherichia coli. Part 1: clinical and

20 Gross RJ, Rowe B. Serotyping of Escherichia coli. In: Sussman M, ed. The virulence of Escherichia coli. Reviews and methods. London; Academic Press, 1985:345-63.

21 Scotland SM, Day NP, Rowe B. Production of a cytotoxi affecting Vero cells by strains of Escherichia coli belonging to traditional enteropathogenic serogroups. FEMS Micro biology Letters 1980;7:15-7.

22 Willshaw GA, Smith HR, Scotland SM, Rowe B. Cloning of genes determining the production of Vero cytotoxin by Escherichia coli. F Gen Microbiol 1985;131:3047-53.

23 Willshaw GA, Smith HR, Scotland SM, Field AM, Rowe B. Heterogeneity of Escherichia coli phages encoding Vero cytotoxins: comparison of cloned sequences determining VT1 and VT2 and development of specific gene probes. VT Gen Microbiol 1987;133:1309-17.

24 Maniatis T, Fritsch EF, Sambrook J. Molecular cloning: laboratory manual. Cold Spring Habor, NY: Cold Spring Harbor Laboratory, 1982.

25 Scotland SM, Willshaw GA, Smith HR, Rowe B. Properties of strains of Escherichia coli belonging to serogroup 0157 with special reference to production of Vero cytotoxins VT1 and VT2. Epidemiology and Infection 1987;99:613-24.

26 Ahmed R, Bopp C, Borczyk A, Kasatiya S. Phage-typing scheme for Escherichia coli 0157:H7. F Infect Dis 1987;155: 806-9.

27 Frost JA, Smith HR, Willshaw GA, Scotland SM, Gross RJ, Rowe B. Phage-typing of Vero-cytotoxin (VT) producing Escherichia coli 0157 isolated in the United Kingdom. Epidemiology and Infection 1989;103:73-81.

28 Farmer JJ, Davis BR. H7 antiserum-sorbitol fermentation medium for detecting Escherichia coli 0157.H7 associated medium for detecting Escherichia coli $0157 . H 7$ associated
with hemorrhagic colitis. $\mathcal{F}$ Clin Microbiol 1985;22:620-5.

29 Chart H, Scotland SM, Rowe B. Serum antibodies to Escherichia coli 0157:H7 in patients with hemolytic uremic syndrome. I Clin Microbiol 1989;27:285-90

30 Chart H, Scotland SM, Smith HR, Rowe B. Antibodies to Escherichia coli 0157 in patients with haemorrhagic colitis and haemolytic uraemic syndrome. $\mathcal{f}$ Clin Pathol 1989;42: 973-6.

31 Smith HR, Rowe B, Gross RJ, Fry NK, Scotland SM Haemorrhagic colitis and Vero cytotoxin-producing Escherichia coli in England and Wales. Lancet 1987; 1062-5.

32 Chapman PA, Wright DJ, Norman P. Verotoxin-producing Escherichia coli infections in Sheffield: cattle as a possible source. Epidemiology and Infection 1989;102:439-45.

33 Ratnam S, March SB, Ahmed R, Bezanson GS, Kasatiya S. Characterization of Escherichia coli serotype 0157:H7. Characterization of Escherichia coli

34 Salmon RL, Farrell ID, Hutchinson JGP, et al. A christening party outbreak of haemorrhagic colitis and haemolytic uraemic syndrome associated with Escherichia col 0157.H7. Epidemiology and Infection 1989;103:249-54.

35 Doyle MP, Schoeni JL. Isolation of Escherichia coli 0157:H7 from retail meats and poultry. Appl Environ Microbiol 1987; 53:2394-6. 